\title{
PEMBERDAYAAN MASYARAKAT PENGRAJIN DAUR ULANG SAMPAH BAHAN PLASTIK KAMPUNG JAMBU CIMAUNG KABUPATEN BANDUNG
}

\author{
Reni Marlina \\ reni.marlina@ekuitas.ac.id \\ Yudi Wahyudin Suwandi \\ yudisuwandi@gmail.com \\ Lina Said \\ linasaid312@yahoo.com
}

\section{SEKOLAH TINGGI ILMU EKONOMI EKUITAS}

\begin{abstract}
ABSTRAK
Kampung Jambu berada di Kecamatan Pasir Jambu. Kabupaten Bandung. Masyarakat Kampung Jambu melalui kelompoknya mengumpulkan sampah plastik untuk diolah menjadi berbagai kerajinan tangan. Namun dalam kegiatannya, masyarakat terkendala bahan baku sampah plastik yang terbatas dan alat pengolahan yang seadanya yang digunakan secara bergantian serta belum dapat menentukan harga pokok penjualan. Tujuan dari pengabdian ini adalah untuk memberdayakan masyarakat pengrajin daur ulang sampah bahan plastic di Kampung Jambu. Metode yang digunakan adalah berbentuk pelatihan pembuatan dan pengelolaan bank sampah, menghitung harga pokok produksi dan harga pokok penjualan, dan manajemen pengelolaan bank sampah dilakukan oleh Tim Kelompok Pengabdian dari STIE Ekuitas. Hasil dari kegiatan pengabdian pada masyarakat ini adalah masyarakat mendapatkan pengetahuan tentang membuat dan mengelola bank sampah sehingga menjadi bermanfaat dan produktif serta menghitung harga pokok penjualan.
\end{abstract}

Kata kunci: Daur Ulang Sampah Plastik, Bank Sampah, Harga Pokok Penjualan, Manajemen Usaha.

\section{PENDAHULUAN}

Kampung Jambu berada di Kecamatan Pasirjambu dan Cimaung, khususnya Desa Cibodas, Cipinang, dan Cikalong. Kecamatan Pasirjambu memiliki luas wilayah $23.958 \quad$ Hektar (www.bandungkab.go.id). Masyarakat Kampung Jambu cukup aktif dan kreatif dalam pengolahan limbah sampah. Masyarakat melalui kelompoknya mengumpulkan sampah plastik untuk diolah berbagai kerajinan tangan. Bekas kemasan air mineral gelas, diolah jadi tas, tempat penyimpanan air mineral, dan lain-lain. Produk hasil daur ulang sampah plastik ada yang dijual ke warga, bahkan pernah juga orang asing yang memesan produknya. Dalam kegiatannya, masyarakat hanya mengumpulkan dan mengolah bahan plastik seadanya di sekitar Kampung Jambu, sehingga bahan bakunya terbatas. Begitu pula dengan alat pengolahan, seperti gunting 
dan lem tembak, menggunakan secara bergantian.

Sebagai penggerak masyarakat Ibu Budi berkeinginan agar masyarakat Kampung Jambu semakin aktif dan kreatif. Ibu Budi mengalami berbagai kendala dalam mengelola sampah plastik ini. Keterbatasan dalam bahan baku, peralatan pengolah, penetapan harga jual, kebutuhan Gerai untuk pemasaran penjualan hasil produk kerajinan serta makanan khas pedesaan menjadi kendala bagi kelompok usaha.

Berdasarkan analisis situasi maka dapat diidentifikasi permasalahan yang dihadapi mitra yaitu terbatasnya bahan baku untuk produk kerajinan yang sulit didapat, sehingga perlu dibentuknya bank sampah. Di samping itu, terbatasnya pengetahuan mengenai manajemen usaha penetapan harga jual, sehingga diperlukan pelatihan tentang manajemen usaha. Kehadiran bank sampah diharapkan akan menjadi solusi dan memberikan keuntungan ganda bagi kelompok pengrajin dan bahan baku untuk bahan kerajinan menjadi mudah. Permasalahan lainnya tentang pengelolaan bank sampah maka diperlukan pelatihan tentang tata kelolanya mulai dari pengelolaan sampah yang masuk juga pengelolaan keuangan, sehingga kehadiran bank sampah memberikan nilai tambah dan pendapatan bagi masyarakat.

\section{METODOLOGI PELAKSANAAN}

Metode pelaksanaan dalam pengabdian ini diawali dengan kegiatan survei awal pada tanggal 15 Januari 2020 untuk dapat mengidentifikasi masalah yang dihadapi oleh Masyakakat Kampung Jambu dan diakhiri dengan kegiatan pelatihan pada tanggal 29 Januari 2020, tentang pengelolaan bank sampah, penghitungan harga pokok penjualan (mengacu pada Dewi \& Kristanto, 2013:12), dengan perincian sebagai berikut:
Tabel. 1 Metode Pelaksanaan Pengabdian

\begin{tabular}{|c|c|c|}
\hline TAHАР & METODE & HASIL \\
\hline $\begin{array}{l}\text { Tahap } \\
\text { awal }\end{array}$ & $\begin{array}{l}\text { - Berdiskusi } \\
\text { dengan } \\
\text { penggerak } \\
\text { PKK dan } \\
\text { perwakilan } \\
\text { masyarakat } \\
\text { Kampung } \\
\text { Jambu RT } 03 \\
\text { RW 12 } \\
\text { - Mengidentifi } \\
\text { kasi masalah } \\
\text { yang } \\
\text { dihadapi } \\
\text { masyarakat } \\
\text { Kampung } \\
\text { Jambu } \\
\text { - Mempersiap } \\
\text { kan bahan- } \\
\text { bahan } \\
\text { pelatihan. }\end{array}$ & $\begin{array}{l}\text { Pemahaman } \\
\text { tentang kondisi } \\
\text { awal dari } \\
\text { masyarakat } \\
\text { kampung } \\
\text { jambu }\end{array}$ \\
\hline $\begin{array}{l}\text { Tahap } \\
\text { pelaksan } \\
\text { aan }\end{array}$ & $\begin{array}{l}\text { - Pelatihan } \\
\text { pengelolaan } \\
\text { Bank } \\
\text { Sampah } \\
\text { - Pelatihan } \\
\text { penghitungan } \\
\text { harga pokok } \\
\text { produksi dan } \\
\text { penetapan } \\
\text { harga pokok } \\
\text { penjualan } \\
\text { - Pelatihan } \\
\text { Manajemen } \\
\text { Usaha } \\
\text { - Implementasi } \\
\text { hasil } \\
\text { pelatihan }\end{array}$ & $\begin{array}{l}\text { - Modul } \\
\text { pelatihan } \\
\text { pengelolaan } \\
\text { bank } \\
\text { sampah, } \\
\text { harga pokok } \\
\text { penjualan } \\
\text { serta } \\
\text { manajemen } \\
\text { usaha } \\
\text { dengan } \\
\text { referensi } \\
\text { dari Ayu } \\
\text { (2013), Hery } \\
\text { (2015),Wula } \\
\text { ndari (2016) } \\
\text { dan } \\
\text { (Amaranti, } \\
\text { Achiraeniwa } \\
\text { ti, As'ad, } \\
\text { Nasution, \& } \\
\text { Satori, } \\
\text { 2016) } \\
\text { Masyarakat } \\
\text { dapat } \\
\text { mengimple- }\end{array}$ \\
\hline
\end{tabular}



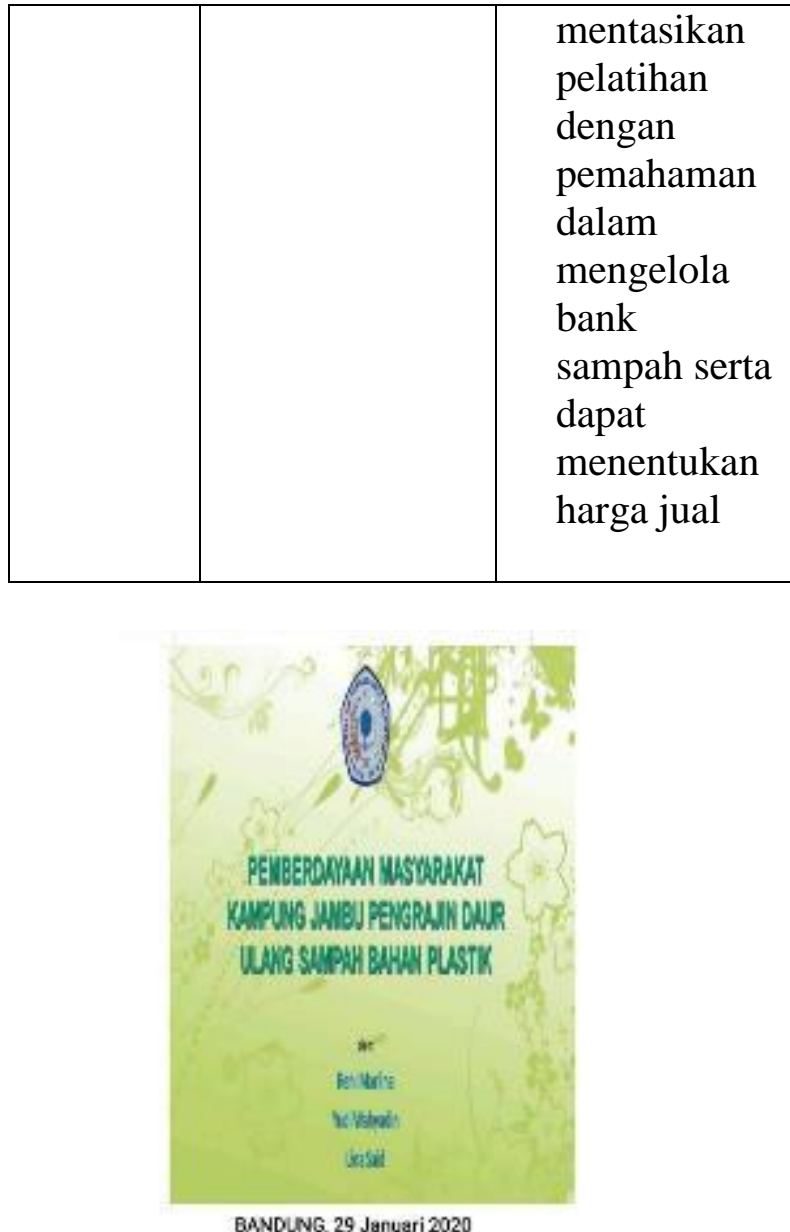

Gambar 1. Cover Modul Pelatihan

\section{HASIL DAN LUARAN}

Ibu Budi, selaku penggerak PKK dan ketua kelompok pengrajin di RW Kampung Jambu, selalu berusaha memberikan edukasi kepada warganya tentang pengelolaan sampah plastik. Namun pada umumnya, warga tidak terlalu peduli dengan kegiatan tersebut. Ibu Budi tidak patah semangat terus-menerus memberikan contoh mengelola sampah plastik. Ada beberapa orang warga yang membantu Ibu Budi dalam mengolah sampah plastik.

Dalam rangka kegiatan pengabdian ini, Ibu Budi mengundang Ketua RW Kampung Jambu, dan Karang Taruna. Pelatihan dilaksanakan di rumah Ibu Budi yang dihadiri oleh 34 peserta yang terdiri dari Ketua RT, Ketua RW, Anggota PKK, dan Karang Taruna. Pelaksanaan pelatihan terkait pembuatan produk olahan sampah berbahan plastik, pelatihan pembuatan dan pengelolaan bank sampah serta perhitungan harga pokok penjualan produk olahan sampah plastik.

Pelatihan diawali dengan penjelasan tentang cara pembentukan pengurus bank sampah di lingkungan RW di wilayah Kampung Jambu, penjelasan mengenai kewajiban/job description dari masingmasing pengurus bank sampah, dilanjutkan mengenai cara membuat bank sampah oleh tim dari STIE Ekuitas. Selanjutnya praktik membuat kerajinan dari produk bank sampah oleh Ibu Budi, dan pelatihan penghitungan harga pokok untuk penjualan produk oleh Tim dari STIE Ekuitas. Dengan adanya pelatihan ini terlihat adanya perubahan yaitu masyarakat yang tadinya tidak tahu cara pembuatan dan pengelolaan bank sampah menjadi tahu dan juga menjadi paham terhadap struktur kepengurusan bank sampah, manajemen usaha bank sampah, pemanfaatan bank sampah serta penghitungan harga pokok sehingga diharapkan masyarakat dapat mengimplementasikannya.

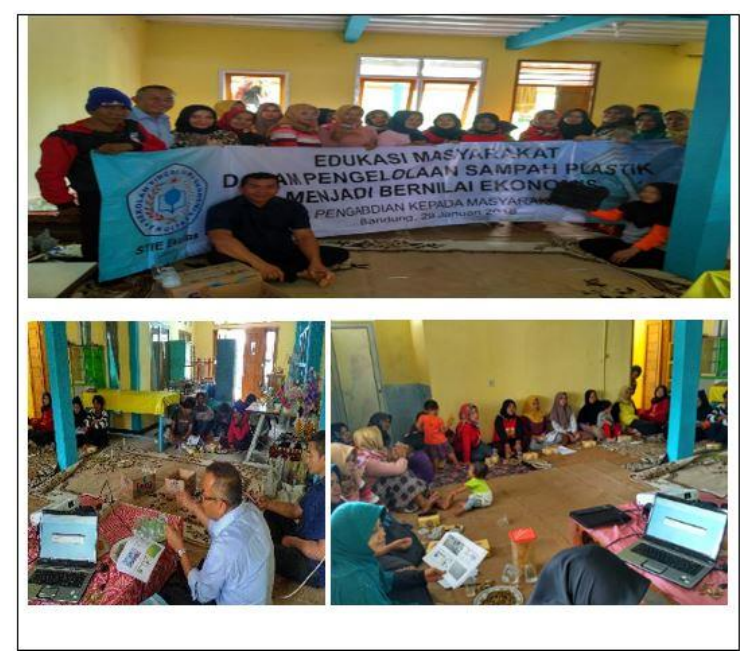

Gambar 2. Pelaksanaan Pengabdian kepada Masyarakat Kampung Jambu 


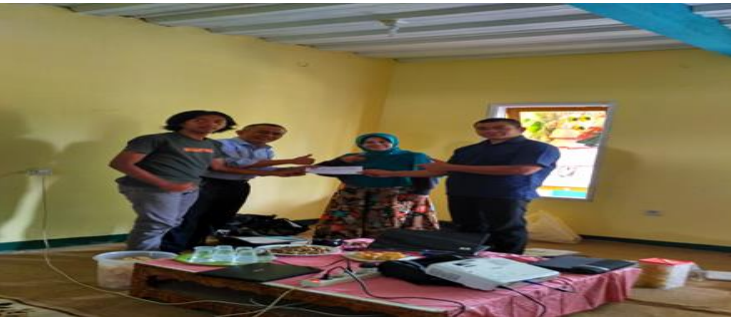

Gambar 3. Penyerahan Sumbangan Untuk Modal Awal pendirian Bank Sampah
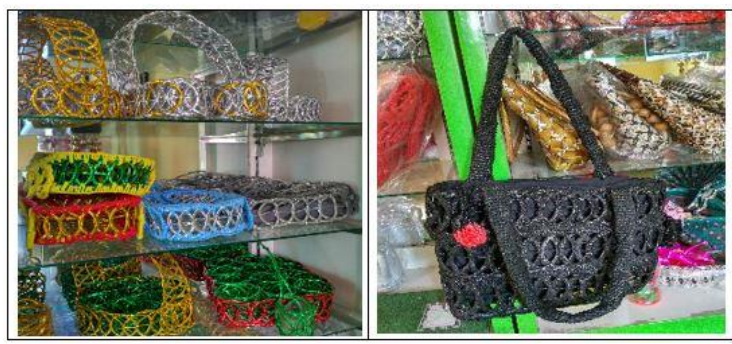

Gambar 4. Hasil Kerajinan Pengolahan Sampah Plastik

Faktor penghambat pengabdian yang dilaksanakan di wilayah Kampung Jambu yaitu warga masih belum menyadari sepenuhnya tentang pentingnya pemilahan sampah, warga masih kurang paham tentang pengelolaan bank sampah dan keterampilan warga dalam memanfaatkan produk olahan sampah masih belum memadai.

\section{KESIMPULAN DAN SARAN}

Masyarakat Kampung Jambu yang mengikuti pelatihan mendapatkan pengetahuan, informasi dan manfaat dari pelatihan pembuatan dan pengelolaan bank sampah serta menentukan harga pokok penjualan produk daur ulang sampah sehingga diharapkan dapat meningkatkan pendapatan dan kesejahteraan peserta yang merupakan warga Kampung Jambu. Saran yang dapat diberikan bahwa kelompok pengrajin ini segera membentuk tim pengurus dengan menggerakkan partisipasi para pemuda melalui Karang Taruna dan akan diberikan pelatihan tahapan pembentukan bank sampah dan pengelolaannya. Tim pengabdian memberikan modal awal untuk berdirinya bank sampah. Ketua Penggerak PKK, disaksikan Ketua RW dan peserta pelatihan dan direncanakan akan dilakukan monitoring dan evaluasi secara periodik untuk memantau perkembangan pembuatan bank sampah di Kampung Jambu dan juga untuk mendapatkan pengetahuan secara mendalam mengenai pengelolaan bank sampah, selanjutnya calon pengurus bank sampah Kampung Jambu dapat melakukan studi banding ke bank sampah yang sudah mengelola bank sampah dengan baik.

\section{DAFTAR PUSTAKA}

Amaranti, R., Achiraeniwati, E., As'ad, N., Nasution, A., \& Satori, M. (2016). Pendampingan Masyarakat dalam Pengolahan Sampah Organik Rumah Tangga untuk Mendukung Program Urban Farming. Ethos (Jurnal Penelitian dan Pengabdian Masyarakat) 4(2), 283-290.

Ayu, A dan Doni, S. (2013). Pembukuan Sederhana Usaha Dagang dan Jasa. Jakarta: Laskar Aksara

Dewi, S P dan Kristanto, S B. (2013). Akuntansi Biaya. Bogor: In Media

Departemen Perdagangan Indonesia. (2008). Pengembangan Ekonomi Kreatif.

Hery. (2015). Cara Mudah Membuat Pembukuan Sederhana. Jakarta: Grasindo

Wulandari, A. (2016). Membangun Indonesia Dari Desa. Semarang: Media Pressindo www.bandungkab.go.id. 